The Key of Knapdale

Author(s): Mary E. Ingram

Source: The Celtic Review, Vol. 4, No. 15 (Jan., 1908), pp. 237-246

Published by:

Stable URL: http://www.jstor.org/stable/30069943

Accessed: 08-03-2016 09:22 UTC

Your use of the JSTOR archive indicates your acceptance of the Terms \& Conditions of Use, available at http://www.jstor.org/page/ info/about/policies/terms.jsp

JSTOR is a not-for-profit service that helps scholars, researchers, and students discover, use, and build upon a wide range of content in a trusted digital archive. We use information technology and tools to increase productivity and facilitate new forms of scholarship. For more information about JSTOR, please contact support@jstor.org. 
prietor, to submit to their Majesties' Government, and deliver up his castles to their forces.' Captain David Kennedy, in his Late History of Europe, published in 1698, after mentioning the surprise at Cromdale, says, 'And in Mull Major Ferguson destroyed several places they held, and forced them to desert the castle of Dowart.' He was recommended for promotion for his services prior to the building of FortWilliam in a letter directly addressed to the king himself by the commander-in-chief: 'Et comme le bien du service,' wrote Mackay shortly after the construction of Fort-William, ' m'oblige de luy representer ceux qui en sont capables et si attachent avec zelle, le Lieutenant Colonel Buchan merit que votre Majesté luy donne une meilleure poste, et Ferguson seroit bien plus capable de commander le regiment de Lauder que Balfour.'

The back of the Jacobite resistance on the west coast was broken by Ferguson and Pottinger, though the Earl of Argyll subsequently led a large force, estimated at 2500 men, into Mull. The influence of the expedition and expectation of its arrival on the fortunes of the Jacobite army in the north has already been seen, and it remains a remarkable though almost forgotten instance of what a small force, boldly but cautiously handled and launched at a region vital to the enemy, can accomplish. It also affords a useful illustration of the combined action of sea-power and a landing force, and of successful co-operation between the navy and army in securing results quite out of proportion to what can be attained by the independent action of either service.

\section{THE KEY OF KNAPDALE}

\section{Mary E. Ingram.}

GIVEN the glory of a summer day, 'tis a wondrously beautiful journey that the traveller makes who escapes from the ' giant factoried city gloom' of Glasgow and its surroundings by the magical waterway of the Clyde to the Highlands. Gradually 
the clangour of shipyard and foundry is smoothed away by the soft swish of the waves, and the air becomes soft and pure as the smoke-wreaths melt into the sunlit blue. For crowded streets and mining villages, with their arid soil and stunted vegetation, there are smiling seaside towns, dainty summer homes set in green woods, and wreathed with glowing flowers. The waves bear many gallant ships and fairy yachts, graceful as the wheeling seagulls in their wake. Behind it all broods the mystic glory of the Highland hills, green, purple, and russet brown in the sunlight. Down the hillsides flash the white waterfalls leaping to the sea below. Winding sea lochs steal away into the solemn embrace of the mountains, their beauties only known to those who follow in loving pilgrimage. The deeply indented coast of Argyle presents many alluring vistas, but one of the fairest is Loch Suibne on the west coast of Knapdale. Over its wooded shores and islands there brood many rich memories-memories of kings and priests, of fierce battles of long ago, and the hymns and prayers of the early saints. Yet but few of the busy summer crowd who throng northward by the Kyles of Bute, and the waters of Loch Fyne to the vale of Crinan, dream of the enchanted land that lies beyond the rocky rampart to the west. Just where Loch Crinan broadens out into its waste of sea and sand there is a road that winds uphill to the left under the shadow of the woods. We follow it: fairy birches tremble in the summer breeze, the craggy hillsides are all aglow with gorgeous bracken and purple heather. And here again the sea. The long fingers of the Atlantic reach up among the clustering woods, fringing with gold and amber seaweed the forest creeks and fairy islets of Loch Suibne. Scarlet rowans flame against the blue of sea and sky, and every cranny of the rocks is fringed with dainty ferns and wreathed with brambles and wild rose. The road winds on, and scarce can we fancy this an arm of the sea till at last, after many windings, we feel the cool breath of the ocean and see the towering peaks of the Jura mountains mirror themselves in the tranquil waters. Looking back we see the creeks and 
bays interspersed with wooded islets melting away into a vista of mountains crowned by the distant majesty of mighty Ben Cruachan. Like its fair sister Loch Katrine, to which it has justly been compared, Loch Suibne owns the spell of the Great Magician. For while the one is graced with the memory of the Lady of the Lake, the other points with pride to the Lord of the Isles, whose ancient stronghold, Castle Suibne, keeps the seaward gate of her Paradise.

Only a scattered homestead here and there, and a village or two that scarcely merits the name, is met with and on the southern side of the loch the road, after passing Castle Suiben and the tiny village of Kilmory, fades away into the heather.

Around the loch rise hills upon hills with the woodlands creeping up their rocky sides, and here and there a Pictish fort keeping watch over the lonely waters. For long ago this was a place of great activity. Successive races have lived, fought, and died here. Wattled boats as well as war-galleys must often have ploughed these creeks and inlets. From time immemorial the kings of the Western Isles kept court at Castle Suibne, which stands on the rocks at the mouth of the loch, and many a fierce siege and bloody battle has raged round it.

Nor are more peaceful memories awanting, for tradition affirms that St. Columba dwelt here ere he went to Iona. At Loch Killisport, an arm of the sea closely adjoining Loch Suibne, a rude cave chapel is believed to have been used by him. It has an altar and font cut in the rock with a cross carved above. On the margin of Loch Suibne, close to the castle, there is a well, called by the natives to this day 'St. Columba's Well,' and believed by them to be the best water in Argyle. It is a matter of history that St. Columba did reside for a time with Conall, king of the Dalriads, who succeeded his uncle Gabhran in 560 A.D., and if that monarch dwelt, as it is asserted, in a fortress on the site of Castle Suibne, the tradition is accounted for. This was the king who gave the island of Iona to the saint, a gift probably 
confirmed by King Brude of the Northern Picts, who about the same time defeated King Conall in battle. Aidan, Conall's successor, was crowned by St. Columba 'Moneist the angell to bleis him - and quhan Sanct Colme laid his hand on the said Aidanis heid, he blessit him and crownit him and prophecet mekill of him his kinrik and his freinds.' There is no doubt that the whole district of Knapdale was in high favour with the immediate successors of St. Columba and those who came after them. Indeed, as has been well pointed out by the late Captain White in his work on Knapdale, no district in the West Highlands possesses such a rich treasure of ecclesiastical remains. Many chapels and hermits' cells were dotted along the margin of Loch Suibne and upon the islands that gem its bosom. Most of these were dedicated to St. Cormac, a disciple of St. Columba, or to St. Maelrubha, who was his kinsman." Upon 'St. Cormac's isle ' there are still ruins of a chapel and cell. Fordoun, who appears to have visited it, says that there was a sanctuary here. A hundred years ago parts of the altar and the piscina were still intact, and also the stone covering of a coffin with the effigy of a priest in his cope. Tradition says that ' Cormac's grave' was here, and into a rocky chamber known as the saint's study no Highlander would dare set foot, believing that whoever did so would remain childless. Two old broken crosses, one of them said to have been brought from Iona, stood near the chapel. An old legend says that one of them was carried off by sacrilegious hands, and taken by boat as far as the Mull of Cantyre. A fierce storm arose, and the craft was unable to make way round that dangerous headland until the terrorstricken sailors cast the cross overboard. Needless to say, the storm abated and the cross floated quietly back to St. Cormac's isle. Castle Suibne, variously spelt as Swen, Sweyn, or Swen, although manifestly the work of different ages, is believed to date from the eleventh century. It is supposed to have been erected by Sweno, Prince of Denmark,

1 May not the hill of Dunrostan overlooking Castle Suibne hold a memory of St. Columba's kinsman and disciple? 
on the site of an earlier castle, though it may have taken its name from Swen de Ergadia or Red Swen, who owned it at the end of the thirteenth century. The walls in some places are six or seven feet thick, and the castle presents in its ruined state the nearest approach to a Norman castle to be found in Scotland. Probably some sort of primitive village sheltered in its lee, represented now by a cluster of homely farm dwellings. It was considered a strategical fortress of great importance in the olden days, and was known as the 'Key of Knapdale.' As the seat of successive races of warrior chiefs, including the mighty Lords of the Isles, it is little wonder that many religious found protection in this seclusion. Probably of old a chapel stood near the castle, but now no vestige remains, and only one crumbling headstone, half buried among the heather, remains of Drum a-chadla. And in the green woods of Daltot, a little way along the shore, the praises of God arose from more than one chapel and cell, of which now only the memory remains. At Keills, on the opposite side of the loch beside a ruined chapel, stands a fine specimen of a Celtic cross.

The Kings of the Isles, maintaining an almost independent sovereignty over the West Highlands and islands, frequently took arms against the King of Scots, who would not acknowledge their claims.

Hence in the fourteenth century we find Alexander, Lord of the Isles, supporting Baliol's cause against Robert the Bruce, and joining forces with John of Lorn in the contest for the crown. Alexander's brother, Angus $\mathrm{Og}$, fought upon the opposite side, and he and Robert Bruce shared the perils of the campaign together. After defeating John of Lorn and his allies, Bruce pursued the Lord of the Isles to his fastness at the mouth of Loch Suibne, where Alexander had entrenched himself. The men of the Isles had a proud belief that they would never be conquered until their enemies could sail across the narrow isthmus that divides Loch Fyne from the outer sea, few being able to make the stormy passage round the Mull of Cantyre. Robert Bruce set the superstition at voL. IV. 
naught by having his boats drawn across the land on planks of wood at Tarbert-a name which here, as elsewhere in Scotland, signifies a portage or isthmus. Once on the further side of Cantyre it was not a long journey to Loch Suibne, and the besiegers attacked the castle from the sea. Bravely did the Lord of the Isles defend his stronghold, but he had at last to submit, and Bruce immediately imprisoned him in Dundonald Castle in Ayrshire, where he is believed to have died.

Clan Donald of the Isles now followed Angus Og their new chieftain in support of Robert Bruce. He is the hero of Scott's Lord of the Isles, and at Bannockburn did gallant service to the royal cause. 'Sir Angus of Ile' and his clan formed the reserve on that great day, and in recognition of their bravery were accorded the privilege of always fighting on the king's right hand on the battlefield. This distinction was jealously prized, and so lately as Culloden the neglect of it helped in great measure to turn the fortunes of the day.

Right royally was Sir Angus recompensed for his loyalty with grants of the broad lands in the west. Remembering the turbulent Alexander, King Robert built himself a castle at Loch Tarbert (where his boats had been dragged across) in order to maintain his royal supremacy in the west. The ruins of this castle still stand picturesquely on the rocks at the mouth of the loch. The Lord of the Isles now took unto himself an Irish bride, who brought with her the curious dowry of one hundred and forty men of every surname from her father's lands, colonists whose descendants people the West Highlands to this day. Sir Angus died in 1330 and was buried in Iona. His tombstone can still be seen, bearing his coat of arms, a ship with hoisted sails, a standard, four lions, and a tree. The inscription runs thus :-

'Hic jacet Angusii filii Domini Angusii MacDomhnill de Ila, 1330.'

His son and successor, 'Good John of Isla,' departed from his father's policy by supporting Edward Baliol, and made an influential marriage with the daughter of the Steward 
of Scotland, afterwards Robert III. Though arrogant in his attitude towards the crown, the new Lord of the Isles was a devoted son of the Church, and the chapels at Loch Suibne, being as it were under his immediate protection, were enriched with his bounty. We read of him making donations to Icolmcille (Iona) and covering the chapels of Elan Eorsag and Elan Suibne, both of them in Loch Suibne, 'with all their appropriate instruments for order and Mass and the service of God for the better upholding of the monks and priests this lord kept in his company.' He too was laid in the Isle of Saints when the end came, and with all the pomp that befitted the 'service and the waking of the King of Fionaghal.'

Troublous times followed for the 'Kingdom of the Isles.' When James I. returned from his English captivity he endeavoured to master his rebellious Highland subjects with a firm hand. Summoning the chiefs to meet him at Inverness he promptly clapped several of them into prison. By this time another Alexander reigned in the Isles, and he, escaping from prison, like his namesake of yore, raised the standard of rebellion. He harried the Royal lands in the north and razed the town of Inverness to the ground. James gave battle at once, and defeated the insurgents. Alexander sent to sue for mercy, but the king would not treat with him as a fellow-sovereign and returned to his capital. Hunted and harassed hither and thither in the Highlands, at last the proud spirit of the great sea lord, 'half prince, half pirate,' gave way. On Easter Sunday 1429, when the king and queen with the court assembled were hearing Mass in Holyrood Abbey, suddenly the Lord of the Isles made a dramatic entrance. Half clad, and the picture of abject misery, he knelt down before the king, offering his naked sword in token of complete submission. Upon the queen's gentle intercession the suppliant's life was spared, but he was imprisoned for a time in the grim old fortress of Tantallon on the Firth of Forth. Would he, looking westward, past the island of Inchcolm, where his mother was in durance for her share in the rebellion, to the far Highland hills, think of his own fastness 
by the gentler waters of Loch Suibne? In 1472 the castle was kept for the Lords of the Isles by Hector Torquill MacNeill, representative of a proud clan. ${ }^{1}$

Soon Castle Suibne and the adjacent lands passed into the hands of Alexander Macmillan through his wife, a daughter of Clan Donald. His title to these possessions is said to have been engraved in Gaelic upon a rock at the mouth of Loch Suibne, but, if so, all vestige of it is worn away. This is believed to be not entirely owing to wind and weather, but to the effacing chisels of Clan Campbell, who ere long acquired the lands of their hereditary foes. The great ivy-mantled tower of Castle Suibne bears the name of Macmillan's Tower, and a fine Celtic cross erected to his memory stands in the little churchyard of Kilmory not far away. The cross bears no date, but is considered to belong to the end of the fourteenth or beginning of the fifteenth century. On its weatherworn surface is a representation of the Crucifixion, with two figures, probably the Blessed Virgin Mary and St. John at the foot of the Cross. Beneath this is a two-handed sword. The reverse of the Cross has a figure of a Highland chief engaged with his dogs in hunting the deer. $\mathrm{He}$ carries a bow and battleaxe, and wears the kilt, a fact which proves the early use of that dress in Scotland. The inscription is-

'Hic est Cryx Alexandri Macmillan.'

There are many interesting old tombstones in this deserted little graveyard, bearing effigies of vested priests and kilted warriors; mouldering away in pathetic decay among the long grass. The roofless little chapel was dedicated to St. Maelrubha, who next to St. Columba was the most popular saint in the West Highlands. He was of Irish extraction,

${ }^{1}$ Once when a Spanish ship had come ashore the MacNeills were making free with the spoil. One of them was asked what the King of Spain would say to their depredations. He haughtily replied that 'MacNeill and his Majesty must settle that between them.' The weddings in MacNeill's time were easily got over. If a tenant's wife died, he had only to apply to the chief for a new one, and the ceremony was performed over a bottle of whisky. 
and according to Scottish tradition died a martyr's death in A.D. 722. From the little hamlet of Kilmory the life is ebbing fast away. There is only one child in the place, and she a stranger, with no playmates save the birds and beasts and the troutlets in the burn. One weaver still plies his busy shuttle, weaving the real old Highland homespun, dyed with the lichens from the rocks and the wild-flowers from the heath. Nowadays, when the cry of 'Back to the Land' rings in our ears, is it too much to hope that some plan may be devised whereby the crowded children of our city slums may find a subsistence in such fair spots as these, and that life may flow back again into the deserted clachans and lonely glens.

Not much more remains to be said of the 'Key of Knapdale.' Frantic struggles took place between rival branches of the great Clan Donald for the title and lands. Another Angus of the Isles married a daughter of Colin, Earl of Argyle at the end of the fifteenth century. Their little son Donald Dubh was captured by the Earl of Athole during a tribal war and given into Argyle's keeping. The same year the custody of Castle Suibne and a grant of the lands of Knapdale was given to Argyle, probably on the child's behalf, but they have remained in the possession of the Campbells ever since. Angus took a fierce revenge for the capture of his son. Assembling his followers he sailed up to Inverlochy, and after harrying the Athole country he pursued the Earl and Countess to St. Bride's Chapel, where they had taken refuge. He dragged them out and carried them off laden with chains. Alas for vengeance! By the way a storm arose, which wrecked many of his treasure-laden galleys. Filled with remorse, the survivors returned stripped to their shirts, and barefooted, to St. Bride's Chapel to implore the Saint's pardon for their sacrilege. The Earl and Countess were set free, and poor turbulent Angus was soon after slain by his own harper. Poor little Black Donald spent most of his life in captivity, much of it in Edinburgh Castle. Although he ever and again escaped and even headed an insurrection, the Government would not acknowledge his claim to the Isles, and the title 
had been wrested from his family in 1493. Embittered by this treatment, it is not surprising that he reverted to the old alliance with England, and designed to further the invasion under Lord Hertford in 1544. Henry vIII. allowed him a pension for his services, and paid $£ 400$ for his funeral expenses when he passed away. He bequeathed his illegitimate son to the care of the King of England, and so ended the direct line of the great Lords of the Isles.

Henceforward the Argyle family kept the Key of Knapdale in their own possession, though Clan Donald ever and again made desperate attempts to regain their lost patrimony. In 1615 the Earl of Argyle assembled his troops to battle under the shadow of Castle Suibne, and it was finally destroyed by 'Colkitto' in the wars of the great Montrose. Thereafter it fell into the ruin we see now, majestic even in decay, its massive walls and deep dungeon telling of the old days of strife and glory. And in the summer days, when the wandering spirit stirs within all who love the magic of the hills and glens, may the glamour of the past as well as the exceeding beauty of the present time lure some travelling feet to this forgotten corner. The Key of Knapdale opens wide the door of memory.

\section{SEA-POEMS}

(Continued from p. 167)

\section{Kenneth Macleod}

VI

\section{AN IONNDRAINN 1}

ON a day of days, according to tradition, a daughter of Macneill of Barra sat in the tower of her husband's castle, in some inland glen far away from the sea and the Western Isles, when lo! like the passing of ghosts at cock-crow, mountains and straths and woods suddenly vanished, and the Western Ocean, with its isles and its

1 Two old people in Eigg kuew this song-Catriona Neill Bhàin (MacDonald q), a native of the island, and Vincent MacEachin, a native of Arisaig. 